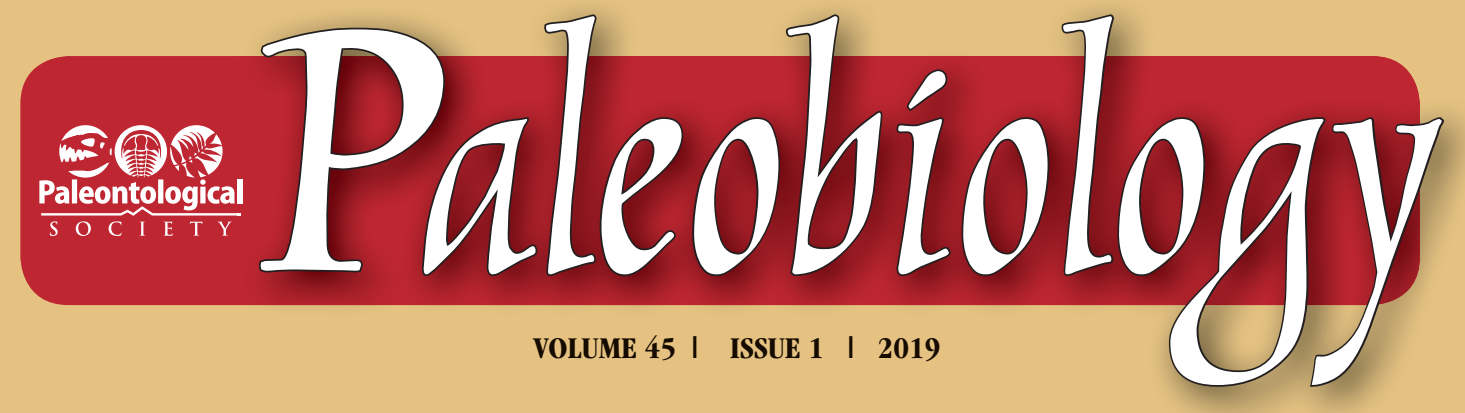

\title{
On The Records
}

Estimation, not significance

Steven M. Holland

Conflict and complementarity of paleontological and molecular chronologies?

Ofir Katz

\section{Articles}

Hyper-longirostry and kinematic disparity in extinct toothed whales

Matthew R. McCurry and Nicholas D. Pyenson

On the probabilities of branch durations and stratigraphic gaps in phylogenies of fossil taxa when rates

of diversification and sampling vary over time

Peter J. Wagner

Diversity patterns of nonmammalian cynodonts (Synapsida, Therapsida) and the impact of taxonomic practice and research history on diversity estimates

Marcus Lukic-Walther, Neil Brocklehurst, Christian F. Kammerer, and Jörg Fröbisch

Climate change and the latitudinal selectivity of ancient marine extinctions

Carl J. Reddin, Ádám T. Kocsis, and Wolfgang Kiessling

Deep-sea ostracod faunal dynamics in a marginal sea: biotic response to oxygen variability and

mid-Pleistocene global changes

Huai-Hsuan May Huang, Moriaki Yasubara, Hokuto Iwatani, Tatsubiko Yamaguchi,

Katsura Yamada, and Briony Mamo

Identifying disruptions to the ecological balance of nature: a foraminiferal example across the initiation

of the Paleocene-Eocene thermal maximum

Lee-Ann C. Hayek, Martin A. Buzas, and Ellen Thomas

Quantifying successional change and ecological similarity among Cretaceous and modern cold-seep faunas Joshua D. Laird and Christina L. Belanger

Paleocommunity mixing increases with marine transgression in Dinosaur Park Formation

(Upper Cretaceous) vertebrate microfossil assemblages

Matthew P. J. Oreska and Matthew T. Carrano

The effects of skeletal asymmetry on interpreting biologic variation and taphonomy in the fossil record Brandon P. Hedrick, Emma R. Schachner, Gabriel Rivera, Peter Dodson, and Stephanie E. Pierce

Biting mechanics determines craniofacial morphology among extant diprotodont herbivores:

dietary predictions for the giant extinct short-faced kangaroo, Simosthenurus occidentalis

D. Rex Mitchell and Stephen Wroe

The function(s) of bone ornamentation in the crocodylomorph osteoderms: a biomechanical model based on a finite element analysis

François Clarac, Florent Goussard, Vivian de Buffrénil, and Vittorio Sansalone

The evolution of the dicynodont sacrum: constraint and innovation in the synapsid axial column

Christopher T. Griffin and Kenneth D. Angielczyk 


\section{PALEOBIOLOGY}

EDITORS

Mark Patzkowsky, Editor-in-Chief, Pennsylvania State University, USA

Kevin Boyce, Stanford University, USA

James Crampton, GNS Science, New Zealand

Nadia Fröbisch, Museum für Naturkunde Berlin, Germany

Wolfgang Kiessling, Friedrich-Alexander University of Erlangen-Nürnberg, Germany

ASSOCIATE EDITORS

Martin Aberhan, Museum für Naturkunde Berlin, Germany

Catherine Badgley, University of Michigan, USA

Paul Barrett, Natural History Museum, London, UK

Julia Clarke, University of Texas, USA

Laurel Collins, Florida International University, USA

Kristina Curry Rogers, Macalester College, USA

John Finarelli, University College Dublin, Ireland

David L. Fox, University of Minnesota, USA

Anjali Goswami, University College London, UK

Jason Head, University of Cambridge, UK

Melanie Hopkins, American Museum of Natural History, USA

Cynthia Looy, University of California Berkeley, USA

Jonathan Marcot, University of California, Los Angeles, USA

MANAGING EDITOR:

Jessica Kastigar, Cincinnati, Ohio,USA, paleobiology@cambridge.org

FOUNDING EDITORS:

Thomas J. M. Schopf and Ralph G. Johnson

\section{MEMBERSHIP INFORMATION}

Members of the Paleontological Society automatically receive electronic subscriptions to Paleobiology and the Journal of Paleontology as a benefit of membership. To apply for individual membership, please go to the Paleontological Society's homepage at http://paleosoc.org/, where links to an electronic application, a printable paper application form, and a complete list of membership benefits are provided under the Membership heading. 
The Patrons Fund was established to broaden the basis of financial support for Paleobiology and thus to encourage paleontological publication.

The Paleontological Society gratefully acknowledges the following Patrons of Paleobiology:

To become a Patron, send a check payable to Paleobiology to:

Paleobiology Patrons Fund The Paleontological Society

P.O. Box 9044

Boulder, CO 80301-9044
Paleobiology Patrons

RICHARD P. ALVORD

ROBERT L. ANEMONE

DAVID J. BOTTJER

WILLIAM A. CLEMENS

PAULO CUSTODI

WILLIAM A. DIMICHELE

DOUGLAS H. ERWIN

BOBBY EZELL

MICHAEL J. FOOTE

JOHN C. HANDLEY

AUGUST ILG

JEREMY B. C. JACKSON

DAVID R. LINDBERG

ERNEST L. LUNDELIUS, JR.

HARUYOSHI MAEDA

GEORGE R. McGHEE, JR.

ARNOLD I. MILLER

WILLIAM C. MILLER, III

MARK E. PATZKOWSKY

DAVID L. RODLAND

IN MEMORY OF TOM SCHOPF

JAMES SPRINKLE

JACEK K. SULANOWSKI

SHERMAN SUTER

ROGER D. K. THOMAS

BRUCE H. TIFFNEY

GEERAT J. VERMEIJ

RON F. WASZCZAK

JOHNNY WATERS

SCOTT L. WING 


\section{SUBSCRIPTION INFORMATION}

Paleobiology [ISSN 0094-8373] is published four times a year (February, May, August, and November) by Cambridge University Press (One Liberty Plaza, 20th Floor, New York, NY 10006) for the Paleontological Society. Members of the Paleontological Society automatically receive electronic subscriptions to Paleobiology and the Journal of Paleontology as a benefit of membership. Institutional subscriptions can be purchased direct from Cambridge University Press or through any major subscription agent. Print-only, online-only, and bundled print and online prices are all available, and subscription prices are tiered according to institution type and size.

Please contact Cambridge University Press for further details:

For customers in North America

Email: subscriptions_newyork@cambridge.org

Phone: (800) 872-7423, option 4

For customers outside of North America

Email: journals@cambridge.org

Phone: +44 (0)1223-32-6070; Fax: +44 (0)1223-32-5150

Downloads of individual articles are available on https://www.cambridge.org/core/journals/ paleobiology.

Reprints of individual articles may be ordered. For information on reprints, please contact Cambridge University Press.

Archives of previous issues are available on https://www.cambridge.org/core/journals/paleobiology.

Permissions All rights reserved. Permissions and reproduction policies, request forms, and contacts are available at: http://www.cambridge.org/about-us/rights-permissions /

\section{ADVERTISING}

To advertise in the journal please contact M. J. Mrvica Associates, 2 West Taunton Avenue, Berlin, NJ 08009; Phone: 856-768-9360; Fax: 856-753-0064; Email: mjmrvica@mrvica.com

\section{ABSTRACTING AND INDEXING}

Abstracting and indexing information for Paleobiology is available at: https://www.cambridge.org/core/ journals/paleobiology/information/abstracting-and-indexing

\section{POSTAL INFORMATION}

Periodicals postage rate paid at New York, NY, and at additional mailing offices. POSTMASTER: Send address changes in the USA, Canada, and Mexico to: Paleobiology, Cambridge University Press, Journals Fulfillment Department, One Liberty Plaza, 20th Floor, New York, NY 10006. Send address changes elsewhere to Paleobiology, Cambridge University Press, Journals Fulfillment Department, UPH, Shaftesbury Road, Cambridge CB2 8BS, England.

Copyright (c) 2019 The Paleontological Society. All rights reserved.

Printed in the United States of America 